\title{
ANALISIS SISTEM DAN PROSEDUR AKUNTANSI ASET DI DINAS PENANAMAN MODAL DAN PELAYANAN TERPADU SATU PINTU DAERAH PROVINSI SULAWESI UTARA
}

\author{
Dewi Kristanti Mentu ${ }^{1}$, Rudy J. Pusung ${ }^{2}$, I Gede Suwetja ${ }^{3}$ \\ 1,2,3 Jurusan Akuntansi, Fakultas Ekonomi dan Bisnis, Universitas Sam Ratulangi, Jl. Kampus Bahu, Manado, \\ 95115, Indonesia
}

Email : dewikristantimentu@yahoo.com

\begin{abstract}
Local government assets are one of the elements of the regional government balance sheet, in the asset information the balance sheet report describes the condition of economic wealth owned by local governments. Analysis of local government assets is carried out to find out more about the wealth and economic potential of the local government so that from this information the public can assess various things. Accounting for assets is an economic resource that is controlled and owned by the local government. The asset accounting systems and procedures a controlling tool in managing assets used by the Regional Work Unit. The purpose of study was to find out how the systems and procedures for asset accounting in the Regional One-Stop Regional Service and Services Office of North Sulawesi Province. The method use in this research is descriptive analysis method. The result show that the application of system and procedure for asset accounting procedures is in accordance with the Regulation of the Minister of Home Affairs No. 17 of 2007. It is recommended that the asset accounting system and procedures at the One Door Investment Service from North Sulawesi. and Integrated Services in accordance with regulations and maintain them again by carrying out technical guidance and socialization to improve the quality of human resources.
\end{abstract}

Keywords: systems, procedures, asset, accounting, analysis

\section{PENDAHULUAN}

Aset pemerintah daerah merupakan salah satu elemen dari pemerintah daerah. Informasi aset dalam laporan neraca menggambarkan kondisi kekayaan ekonomi yang dimiliki pemerintah daerah, melalui informasi aset yang disajikan dalam neraca, pembaca laporan keuangan dapat melihat bahwa pemerintah daerah A secara ekonomi relatif lebih kaya dibandingkan pemerintah $\mathrm{B}$ tanpa si pembaca melihat secara langsung ke masingmasing pemerintah daera tersebut. Kondisi kekayaan pemerintah daerah disimbolkan dalam neraca berupa jumlah aset lancer, invetasi jangka panjang, dana cadangan, asset tetap, dan aset lainnya yang dimiliki. "Analisis aset pemerintah daerah dilakukan untuk mengetahui secara lebih dalam tentang kekayaan dan potensi ekonomi pemerintah daerah sehingga dari informasi tersebut masyarakat dapat menilai berbagai hal, misalnya seberapa menarik melakukan investasi di wilayah itu terkait dengan keamanan berinvestasi serta potensi keuntungan yang bisa didapat, seberapa nyaman tinggal di daerah tersebut terkait dengan kelengkapan sarana dan prasarana publik, seberapa besar kemandirian keuangan pemerintah daerah, seberapa besar potensi kerjasama kemitraan dengan pemerintah daerah, dan sebagainya". Sistem pemerintah yang berubah dari sistem terpusat menjadi sistem otonomi daerah telah memberi dampak yang besar bagi sistem penyelenggaran pemerintahan di ruang lingkup kinerja juga memberi dampak pada pengaturan sistem keuangan pemerintahan daerah dan otonomi daerah menuntut pemerintahan daerah untuk lebih memberikan pelayanan publik yang didasarkan atas asas pelayanan publik yang meliputi: transparansi, akuntabilitas, 
kondisional, partisipatif, kesamaan hak, keseimbangan hak dan kewajiban demi tercapainya "good governance". Suatu pemerintahan yang baik (good governance) adalah pemerintahan yang memiliki karaketeristik diakui oleh masyarakat atau memiliki legimitasi, berakuntabilitas, mempunyai kemampuan untuk meformulasikan kebijakan dan menyediakan jasa, dan menghormati hak asasi manusia, serta menjunjung dan menegakkan hukum. Indonesia bagian dari masyarakat dunia memiliiki kewajiban untuk terus-menerus berpatisipasi dalam mewujudkan pemerintahan yang baik (good governance), pemereintahan yang baik stidaknya ditandai dengan tiga elemen yaitu tranparansi, partisipasi, dan akuntabilitas. Transparansi dibangun atas dasar kebebasan memperoleh informasi. Partisipasi maksudnya mengikutsertakan keterlibatan masyarakat dalam pembuatan keputusan baik secara langsung maupun tidak langsung melalui lembaga perwakilan yang dapat menyalurkan aspirasinya. Sedangkan akuntabilitas adalah pertanggungjawaban kepada publik atas tiap aktivitas yang dilakukan.

\section{TINJAUAN PUSTAKA}

Akuntansi. Menurut Weygandt, Kimmel, Kieso (2011) "akuntansi adalah sistem informasi yang mengidentifikasi, mencatat, dan mengkomunikasikan peristiwa ekonomi dari suatu organisasi untuk pengguna yang tertarik". Menurut Odianonsen, Stephen, Ajay (2014:2) "The main purpose of accounting is to provide information to interested parties to make full, timely and reliable". "Akuntansi adalah suatu proses pengidentifikasian, pengukuran, pencatatan, dan pelaporan transaksi ekonomi (keuangan) dari suatu organisasi/entitas yang dijadikan sebagai informasi dalam rangka pengambilan keputusan ekonomi oleh pihak-pihak yang memerlukan" (Halim dan Kusufi, 2012 : 36)

Akuntansi Pemerintahan. Ada beberapa pengertian yang telah dikemukakan yaitu sebagai berikut. Menurut Halim, $d k k$ (2010:29) "menyatakan pemerintahan adalah perusahaan yang menghasilkan produk berupa jasa pelayanan yang bersifat langsung dinikmati oleh masyarakat maupun secara tidak langsung dinikmati masyarakat”. Deddi, $d k k$ (2012: 4) "akuntansi pemerintahan mengkhususkan dalam pencatatan dan pelaporan transaksi-transaksi yang terjadi di badan pemerintahan".

\section{Tujuan Akuntansi Pemerintahan}

1. Pertanggungjawaban. Dalam tujuan pertanggungjawaban pemerintah harus memberikan informasi keuangan secara lengkap, memberikan informasi keuangan secara cermat, dalam bentuk dan waktu yang tepat, yang berguna bagi pihak yang bertanggungjawab yang berkaitan dengan operasi unit-unit pemerintahan. Tujuan pertanggungjawaban ini mengharuskan tiap orang atau badan yang mengelola keuangan negara, memberikan pertanggungjawaban dan perhitungan.

2. Manajerial. Dalam tujuan manajerial, memberikan informasi keuangan untuk perencanaan, penganggaran, pelaksanaan, pemantauan, pengendalian anggaran, rumusan kebijakan, pengambilan keputusan, dan penilaian kinerja pemerintah adalah tujuan yang diharapkan dapat dicapai dengan adanya akuntansi pemerintah.

3. Pengawasan. Memiliki arti bahwa informasi yang dihasilkan akuntansi pemerintahan harus memungkinkan untuk terselenggarakan pemeriksaan oleh aparat pengawas.

Dari keterangan tersebut diatas, diharapkan dengan adanya akuntansi pemerintah, mampu membangun hubungan kepercayaan yang baik antara pemerintah pusat maupun daerah dengan masyarakat melalui informasi yang disajikan dalam laporan keuangan dengan tujuan untuk mensejahterakan masyarakat.

Karakteristik Akuntansi Pemerintah. "Mardiasmo (2009:3) mengatakan karakteristik akuntansi pemerintahan adalah : karakteristik akuntansi pemerintahan disebabkan karena adanya lingkungan yang mempengaruhi. Organisasi sektor publik bergerak dalam lingkungan kompleks dan turbulence". 
Pengertian Akuntansi Sektor Publik. Menurut Mir \& Sutiyono (2013:97) "public sector accounting field that has the scope of high state institutions and departements under it, local governments, foundations, political parties, universities, and non-profit organizations more". Halim (2014:97) "menyatakan bahwa akuntansi sektor publik adalah sebuah kegiatan jasa dalam rangka penyediaan informasi kuantitatif, terutama yang bersifat keuangan dari entitas pemerintah guna pengambilan keputusan ekonomi dari pihak-pihak yang berkepentingan atas berbagai alternatif dalam tindakan". "Organisasi sektor publik merupakan sebuah entitas ekonomi dengan sumber daya ekonomi yang besar dan dikelola oleh pemerintah". Menurut Mahmudi (2011:13) "peran akuntansi dalam organisasi sektor publik antara lain sebagai berikut":

1. Pengelolan Keuangan Negara. Manajemen keusangan sektor publik terkait dengan sebagai berikut : (a) Manajemen Pendapatan Negara; (b) Manajemen Belanja Negara; (c) Manajemen Utang Negara; (d) Manajemen Aset Negara; (e) Manajemen Kas; dan (f) Manajemen Investasi Publik. Sementara itu peran akuntansi manajemen sektor publik dalam pengelolaan keuangan negara meliputi sebagai berikut : (a) Perencanaan strategi sektor publik; (b) Pemberian informasi biaya sektor publik; (c) Penilaian investasi publik; (d) Penganggaran sektor publik; (e) Pengendalian pusat pertanggungjawaban; (f) Penentuan harga atau tarif pelayanan; dan (g) Pengukuran kinerja.

2. Laporan Keuangan. Akuntansi sektor publik memiliki peran penting dalam penyusunan dan penyajian laporan keuangan sektor publik.

3. Pemeriksaan. Pelaksanaan audit sektor publik membutuhkan tenaga ahli di bidang akuntansi dan auditing. Kebutuhan terhadap auditing sektor publik sangat tinggi untuk memberikan jasa atestasi dan audit assurance.

4. Akuntansi untuk tata kelola pemerintahan yang baik. Pada organisasi sektor publik, prinsip good public governance hampir sama dengan prinsip Good Corporate Governance (GCG) pada sektor bisnis bahkan lebih luas lagi. Prinsip good governance menurut UNDP terdiri atas: (a) transparansi (transparency); (b) akuntabilitas (accountability); (c) responsivitas (responsiveness); (d) keadilan (equity); (e) partisipasi (participants); (f) aturan hukum (rule of law); (g) konsensus (consensus orientation); (h) efisiensi dan efektivitas (efficiency and effectiveness); dan (i) visi strategi (strategic vision).

Sistem Akuntansi Pemerintahan Daerah. Sistem akuntansi pemerintah daerah beradasarkan peraturan pemerintah "Ketentuan pasal 232 dari Peraturan Menteri Dalam Negeri Nomor 13 Tahun 2006 yang merupakan pedoman pelaksanaan terhadap Peraturan Pemerintah Nomor 58 Tahun 2005 tentang pengelolaan keuangan daerah, menyebutkan bahwa sistem akuntansi pemerintah daerah dilaksanakan oleh Pejabat Pengelola Keuangan Daerah (PPKD) pada Satuan Kerja Pengelola Keuangan Daerah (SKPD) dan sistem akuntansi satuan kerja perangkat daerah (SKPD) dilaksanakan oleh Pejabat Penatausahaan Keuangan Satuan Kerja Perangkat Daerah (PPK-SKPD)" (Hariadi et al 2010:119)

Pengelolaan Keuangan Daerah. "Menurut Permendagri No. 13 Tahun 2006 tentang Pedoman Pengelolaan Keuangan Daerah, pengelolaan keuangan daerah merupakan keseluruhan kegiatan yang meliputi perencanaan, pelaksanaan, dan pelaporan, Pertanggungjawaban dan pengawasan keuangan daerah".

Sistem dan Prosedur Akuntansi Aset. Pengertian Sistem dan prosedur "sistem adalah kumpulan elemen yang saling berkaitan dan bekerja sama dalam melakukan kegiatan untuk mencapai suatu tujuan". "Menurut Diana dan Setiawati (2011:3) pendekatan sistem yang lebih menekankan pada prosedur mendefinisikan sistem sebagai berikut suatu sistem adalah serangkaian bagian yang saling tergantung dan bekerja sama untuk mencapai tujuan tertentu. Sedangkan "prosedur didefinisikan sebagai berikut suatu uraian kegiatan klerikal yang melibatkan beberapa orang dalam satu pemerintahan yang dibuat untuk menjamin 
penanganan secara transaksi". "Sistem dan prosedur akuntansi aset adalah alat pengendali dalam pengelolaan aset yang dikuasai atau digunakan Satuan Kerja Perangkat Daerah".

Prosedur Akuntansi Aset. Prosedur akuntansi aset meliputi "serangkaian proses baik manual maupun terkomputerisasi mulai dari pencatatan dan pelaporan akuntansi atas perolehan hingga pemeliharaan, rehabilitasi, penghapusan, pemindahtanganan, perubahan klasifikasi, dan penyusutan terhadap aset yang dikuasai/digunakan SKPD dan/atau SKPKD".

\section{Penelitian Terdahulu}

1. Akhyar Tipan (2015) dalam penelitian Analisis Perlakuan Akuntansi Aset Tetap Pada Dinas Pekerjaan Umum (PU) Provinsi Sulawesi Utara. Hasil penelitian menunjukkan bahwa Perlakuan Akuntansi Terhadap Aset Yang Dilaksanakan Di Dinas Pekerjaan Umum Provinsi Sulawesi Utara Telah Berjalan Dengan Baik.

2. Kolinug Monica (2015) dalam penelitian Analisis Pengelolaan Aset Tetap Pada Dinas Pendapatan, Pengelolaan Keuangan Dan Aset Kota Tomohon Hasil penelitian menunjukkan bahwa DPPKAD Telah Menerapkan 6 Sistem Pengelolaan Aset Tetap dan terdapat 1 sistem yang belum diterapkan.

\section{METODE PENELITIAN}

Jenis Penelitian. Penelitian yang digunakan yaitu deskriptif kualitatif. Data deskriptif pada umumnya dikumpulkan melalui daftar pertanyaan dalam survey, wawancara ataupun observasi. Dan jenis data yang berbentuk deskriptif seperti gambaran umum organisasi, informasi operasional organisasi.

Tempat dan Waktu Penelitian. Penelitian ini dilakukan di Dinas Penanaman Modal Dan PTSP Daerah Provinsi Sulawesi Utara dari bulan Maret sampai dengan selesai.

Jenis Data. Data Kualitatif adalah data yang disajikan dalam bentuk kata-kata yang mengandung makna dan tidak dapat dikuantitatifkan, data kualitatif yang digunakan dalam penelitian ini adalah data sistem dan prosedur akuntansi aset dalam hal ini adalah pencatatan untuk aset di Dinas Penanaman Modal Dan PTSP Daerah Provinsi Sulawesi Utara.

Sumber data. Dalam penelitian ini penulis menggunakan data primer berupa laporan akuntansi aset dan data sekunder berupa profil dan struktur organisasi dari Dinas Penanaman Modal Dan PTSP Daerah Provinsi Sulawesi Utara.

Teknik Pengumpulan Data. Pengumpulan data yang diperlukan, penulis menggunakan 2 (dua) teknik pengumpulan data yaitu:

1. Wawancara, dengan mengadakan wawancara dalam hal ini tanya jawab dengan pimpinan dan staf yang ditujukan untuk mengadakan penelitian terhadap sistem dan prosedur akuntansi aset menyangkut masalah yang diangkat.

2. Dokumentasi cara pengumpulan data dengan menggunakan arsip dan dokumen-dokumen dari Dinas yang bersangkutan.

Metode Analisis Data. Dalam menganalisa data yang terkumpul penulis menggunakan metode deskriptif dengan pengambilan data kualitatif yang bertujuan untuk memahami dan membandingkan penelitian dengan cara mengklasifikasikan dan mengumpulkan data yang berhubungan dengan aset pemerintah dengan landasan teori yang ada. Adapun metode membandingkan antara metode pengukuran pengakuan, pelaporan, pencatatan, pengungkapan apakah sudah sesuai dengan Permendagri No. 17 tahun 2007 kemudian dianalisis lebih lanjut dengan cara diadakan pembahasan masalah untuk menuju pada kesimpulan dan selanjutnya akan diberi saran-saran bahan input bagi pemerintah. 


\section{HASIL PENELITIAN DAN PEMBAHASAN}

Akuntansi pada Dinas Penanaman Modal Dan Pelayanan Terpadu Satu Pintu

Daerah Provinsi Sulawesi Utara. Dalam pelaksanaan kegiatan khususnya yang berkaitan dengan belanja modal pada SKPD Dinas Penanaman Modal Dan PTSP dilakukan dengan 2 tahap yaitu akuntansi transaksi belanja satuan kerja dan akuntansi aset satuan kerja.

1. Transaksi Belanja

a. Transaksi belanja di Satker dicatat oleh pegawai penatusahan keuangan Satker (PPKSatker) transaksi dicatat harian pada saat kas dibayarkan ole bendahara pengeluaran atau pada saat menerima tembusan bukti transfer ke pihak ketiga.

b. Penerimaan kembali belanja yang terjadi pada periode pengeluaran belanja, dicatat sebagai pengurang belanja, apabila diterima pada periode berikutnya koreksi belanja dicatat sebagai pendapatan lain-lain (PP No. 24 Tahun 2005).

c. Transaksi belanja modal pencatatan dilakukan dengan dua jurnal. Satu jurnal untuk mencatat belanja, dan yang lainnya untuk mencatat aset yang diperoleh dari transaksi belanja modal tersebut.

d. Transaksi belanja diSatker dilakukan dengan dua cara yaitu: (1) Pembayaran dengan SP2D UP/GU/TU; dan (2) Pembayaran dengan SP2D LS.

e. Transaksi penerimaan pihak ketiga (PFK) merupakan transaksi transtoris berupa penerimaan kas dari pihak ketiga yang sifatnya titipan dan harus diakui sebagai utang.

2. Dokumen yang Digunakan

Dokumen yang disajikan dalam pencatatan transaksi belanja ini adalah sebagai berikut:

a. Belanja dengan mekanisme LS. Dokumen yang berupa: SP2D, nota debit bank, bukti pengeluaran lainnya.

b. Belanja dengan mekanisme UP/UG/TU. Dokumen sumber berupa: bukti pengeluaran SPJ.

c. Penerimaan PFK. Dokumen sumber berupa: surat setoran, nota kredit, bukti potongan, dan bukti pengeluaran lainnya".

3. Jurnal Transaksi Belanja. Jurnal yang dibuat oleh sehubungan dengan transaksi belanja adalah sebagai berikut:

a. Penerimaan SP2D UP/GU/TU oleh bendahara Satker

Kas dibendahara Pengeluaran $\quad \mathrm{xx}$

RK-PPKD $\quad \mathrm{xx}$

b. Pelaksanaan belanja dengan menggunakan uang persediaan yang sebelumnya dicairkan melalui SP2D UP/GU/TU

Belanja

$\mathrm{XX}$

Kas dibendahara pengeluaran

$\mathrm{XX}$

c. Pelaksanaan belanja dengan menggunakan SP2D LS

Belanja

RK-PPKD

$\mathrm{XX}$

(pejabat penatausahaan keuangan daerah)

$\mathrm{XX}$

Khusus untuk transaksi belanja yang menghasilkan aset tetap, SKPD Dinas Penanaman Modal Dan PTSP juga menganggap penambahan aset sesuai dengan jenisnya dengan menjurnal sebagai berikut:

a. Belanja modal yang menggunakan uang persediaan

Belanja modal

$\mathrm{XX}$

Kas dibendahara pengeluaran

$\mathrm{XX}$

b. Belanja modal dengan menggunakan SP2D LS

Belanja modal

RK-PPKD

XX

XX 
c. Pengakuan aset tetap dari belanja modal oleh Dinas Penanaman Modal Dan PTSP Aset tetap

$\mathrm{xX}$

$$
\begin{aligned}
& \text { Ekuitas dana invetasi } \\
& \text { Dinvestasikan dalam aset tetap }
\end{aligned}
$$

$\mathrm{XX}$

$\mathrm{XX}$

Analisis Sistem Dan Prosedur Pengelolaan Aset/Barang Milik Daerah. Sesuai dengan Permendagri Nomor 17 Tahun 2007 Pengelolaan barang daerah merupakan rangkaian kegiatan dan tindakan terhadap barang daerah yang meliputi:

Perencanaan Kebutuhan dan Penganggaran. Dalam perencanaan kebutuhan dan penganggaran Dinas Penanaman Modal Dan PTSP Daerah Provinsi Sulawesi Utara meneliti seluruh Daftar Kebutuhan Barang Milik Daerah (DKBMD), setelah diteliti kemudian Dinas Penanaman Modal Dan PTSP menyampaikan kepada Kepala Daerah melalui pengelola, untuk Daftar Kebutuhan Barang Milik Daerah (DKBMD) dalam pelaksanaan anggaran belanja tahunan, daftar tersebut akan dijadikan pedoman dalam pelaksanaan pengadaan dan pemeliharaan barang milik daerah. Dinas Penanaman Modal Dan PTSP sebagai salah satu bagian dari Pemerintahan di Daerah Provinsi Sulut melakukan perencanaan atas barang yang dibutuhkan oleh bagian-bagian atau unit kerja dengan dimaksud perencanaan atas aset yang sudah rusak, yang mulai rusak, maupun barang yang sudah tua serta rencana dan kebutuhan lain yang dianggap penting untuk dimasukkan dalam perencanaan. Setelah melakukan perencanaan Dinas Penanaman Modal Dan PTSP kemudian menyusun rencana kebutuhan barang dan rencana kebutuhan pemeliharaan barang dengan memperhatikan standar sarana prasarana yang telah ditetapkan serta ketersediaan barang kemudian disampaikan kepada pengelola melalui pembantu pengelola (PPK SKPD) untuk kemudian diteliti dan disusun mejadi Rencana Daftar Kebutuhan Barang Milik Daerah (RDKBMD), Rencana Kebutuhan Pemeliharaan Barang Milik Daerah (RKPBMD) dan Rencana Daftar Kebutuhan Pemeliharaan Barang Milik Daerah (RDKPBMD).

Analisis Terhadap Perencanaan Kebutuhan Anggaran. Untuk prosedur perencanaan sudah sesuai dengan ketentuan/peraturan yang berlaku, di mana Dinas Penanaman Modal dan PTSP Daerah Provinsi Sulawesi Utara telah melaksanakan perencanaan sesuai kebutuhan.

Penerimaan Penyimpanan dan Penyaluran. Penerimaan barang milik daerah dimulai saat barang diterima oleh penyimpan barang/pengurus barang di Dinas Penanaman Modal Dan PTSP yang dilaksanakan digudang penyimpanan. Peneriman barang didasarkan pada surat perintah kerja/surat perjanjian dan dokumen yang jelas yang menyatakan macam/jenis harga dan spesifikasi barang, kemudian barang diperiksa oleh panitia pemeriksaan sesuai dengan surat perintah kerja. Hasil pemeriksaan barang kemudian dituangkan dalam berita acara dan setelah diperiksa barang selanjutnya disimpan dalam gudang. Contoh dokumen penerima penyimpanan dan penyaluran:

1. Format Surat Keputusan Pembentukan Panitia Pemeriksaan Barang/Jasa.

2. Berita Acara Penerimaan Barang.

3. Buku Penerimaan Barang.

4. Buku Pengeluaran Barang.

5. Buku Inventaris.

6. Buku Barang Pakai Habis.

7. Kartu Barang.

8. Kartu Persediaan Barang

Analisis Terhadap Penerimaan Penyimpanan dan Penyaluran. Penerimaan penyimpanan dan penyaluran sudah sesuai dengan ketentuan/peraturan yang berlaku, dimana Dinas Penanaman Modal dan PTSP Daerah Provinsi Sulawesi Utara telah melakukan penerimaan 
sesuai dengan prosedur, kemudian barang yang diterima disimpan ditempat penyimpanan sebelum barang disalurkan ke unit-unit organisasi.

Penggunaan. Dalam penggunaan aset/barang milik daerah, Dinas Penanaman Modal Dan PTSP melakukan inventarisasi dan pencatatan terhadap aset/barang milik daerah, yang dimiliki disertai dengan usulan status penggunaan kepada Kepala Daerah melalui pengelola untuk kemudian diteliti dan ditetapkan oleh Kepala Daerah. Setelah statusnya ditetapkan Dinas Penanaman Modal dan PTSP kemudian melakukan inventaris dan pencatatan terhadap aset/barang milik daerah yang digunakan. Namun dalam pelaksanaan penggunaan masih terdapat Aset Milik Daerah yang tidak digunakan sesuai dengan ketentuan contohnya kendaraan dinas yang masih digunakan untuk kepentingan pribadi pemegang atau kuasa pengguna barang yang digunakan diluar jam dan hari kerja.

Analisis Terhadap Penggunaan. Penggunaan sudah sesuai sistem prosedur dengan ketentuan/peraturan yang berlaku, dimana Dinas Penanaman Modal dan PTSP Daerah Provinsi Sulawesi Utara, telah menggunakan aset/barang milik daerah sesuai dengan ketentuan.

Penatausahaan. Dalam penatausahaan barang milik daerah dilakukan 3 (tiga) kegiatan yang meliputi kegiatan pembukuan, inventarisasi dan pelaporan. Setelah itu, pembantu pengelola merekap buku inventaris tersebut menjadi buku induk inventaris. Dalam pelaksanan penatausahaan, Dinas Penanaman Modal dan PTSP melakukan kordinasi pencatatan dan pendaftaran barang milik daerah ke dalam Daftar Barang Milik Daerah (DBMD) serta menginvetarisasikan barang dengan melakukan pencatatan dan meneliti seluruh laporan pengguna barang secara triwulan, semesteran, dan tahunan dari masing-masing SKPD lewat jumlah maupun nilai dibuat rekapitulasinya.

Analisis Terhadap Penatausahaan. Penatausahaan sudah sesuai dengan ketentuan/peraturan yang berlaku dimana Dinas Penanaman Modal dan PTSP Daerah Provinsi Sulawesi Utara telah melakukan pencatatan dan pendaftaran barang sesuai dengan Kartu Inventaris Barang (KIB).

Pemanfaatan. Pemanfaatan merupakan pendayagunaan barang milik daerah yang tidak dipergunakan sesuai tugas pokok dan fungsi SKPD dalam bentuk pinjam pakai, sewa, kerjasama pemanfaatan, bangun guna serah, bangun serah guna dengan tidak merubah status kepemilikan. Pemanfaatan barang milik daerah berupa tanah/bangunan dilaksanakan oleh pengguna setelah mendapat persetujuan Kepala Daerah. Dalam pelaksanaan pemanfaatan aset daerah, Dinas Penanaman Modal dan PTSP melaksanakan tugasnya menginventarisasikan dan mencatat serta memanfaatkan aset/barang milik daerah sesuai dengan kebutuhan yang ada. Untuk pemanfaatan sampai saat ini Dinas Penanaman Modal dan PTSP tidak ada penyewaan berupa aset milik daerah.

Analisis Terhadap Pemanfaatan. Dalam pelaksanaan pemanfaatan aset/barang milik daerah, sampai saat ini belum ada pemanfaatan seperti pinjam pakai, penyewaan, bangun serha guna, dan bangun guna serah di Dinas Penanaman Modal dan PTSP Daerah Provinsi Sulawesi Utara.

Pengamanan dan Pemeliharaan. Pengamanan merupakan tindakan pengendalian dan penertiban dalam pengurusan barang milik daerah secara fisik, administratif dan tindakan hukum. Pengamanan dilakukan terhadap barang milik daerah berupa barang inventaris dalam proses pemakaian dan barang persediaan dalam gudang yang diupayakan secara fisik, administratif dan tindakan hukum. Dalam hal pengamanan, secara administratif Dinas Penanaman Modal dan PTSP melakukan pencatatan terhadap barang-barang invetaris yang ada. Untuk pengamanan fisik Dinas Penanaman Modal dan PTSP melakukan penyimpanan barang yang dilakukan digudang maupun ditempat terbuka, pemagaran dan pemasangan tanda kepemilikan. Sedangkan hal pemeliharaan yang disesuaikan dengan jenis barang untuk menjaga barang/aset terhindar dari berbagai kerusakan. Contoh beberapa bentuk 
pemeliharaan yang rutin dilakukan adalah pengecetan gedung kantor dan perbaikan (service) kendaraan dinas maupun barang elektronik itulah prosedur Pemeliharaan di Dinas Penanaman Modal dan PTSP.

Analisis Terhadap Pengamanan dan Pemeliharaan. Pengamanan dan pemeliharan sudah sesuai dengan ketentuan/peraturan yang berlaku dimana Dinas Penanaman Modal dan PTSP Daerah Sulawesi Utara telah melakukan pengamanan secara administrasi dan fisik serta melakukan beberapa bentuk pemeliharaan yang disesuaikan dengan jenis barang.

Penghapusan. Dalam penghapusan barang milik daerah di Dinas Penanaman Modal dan PTSP melakukan identifikasi barang yang perlu dihapus oleh karena suatu alasan untuk dihapuskan. Setelah melakukan identifikasi, selanjutnya adalah melakukan pengusulan kepada kepala daerah melalui pengelola untuk aset daerah yang tidak layak dan harus dihapuskan didasarkan pada pertimbangan yang ada dan setelah disetujui kemudian diterbitkan surat keputusan kepada Dinas Penanaman Modal dan PTSP menindaklanjuti penghapusan barang milik daerah dan melakukan pencatatan atas aset yang telah dihapuskan.

Analisis Terhadap Penghapusan. Penghapusan sudah sesuai dengan ketentuan/peraturan yang berlaku dimana Dinas Penanaman Modal dan PTSP Daerah Provinsi Sulawesi Utara sudah mlaksanakan pengusulan terhadap aset daerah yang layak untuk dihapuskan dan melakukan pencatatan atas aset/barang yang telah disetujui untuk dihapuskan.

\section{KESIMPULAN DAN SARAN}

\subsection{Kesimpulan}

Dari hasil penelitian yang telah didapatkan maka dapat disimpulkan beberapa hal, sebagai berikut:

1. Hasil penelitian menunjukkan pelaksanaan proses sistem dan prosedur akuntansi asset/barang milik daerah pada Dinas Penanaman Modal Dan Pelayanan Terpadu Satu Pintu Daerah Provinsi Sulawesi Utara secara keseluruhan sudah sesuai dengan Permendagri Nomor 17 Tahun 2007.

2. Terdapat subsistem Pemanfaatan yang belum sesuai dengan ketentuan/peraturan yang berlaku, hal ini disebabkan karena Dinas Penanaman Modal Dan Pelayanan Terpadu Satu Pintu Daerah Provinsi Sulawesi Utara tidak melakukan bentuk-bentuk pemanfaatan atas aset yang dimiliki".

\subsection{Saran}

Berdasarkan pembahasan dan simpulan yang telah dikemukakan sebelumnya, maka saran yang dapat diberikan yaitu, sebagai berikut :

1. Tingkatkan lagi pelaksanan sistem dan prosedur akutansi aset/barang milik daerah agar lebih efektiif dan baiknya dilaksanakan sesuai Peraturan Menteri Dalam Negeri Nomor 17 Tahun 2007 tentang Pedoman Teknis Pengelolaan Barang Milik Daerah”.

2. Dinas Penanaman Modal Dan PTSP Daerah Provinsi Sulawesi Utara dalam melaksanakan Sistem dan Prosedur Akuntasi Aset agar melakukan bentuk-bentuk pemanfaatan atas aset/barang yang dimiliki.

\section{DAFTAR PUSTAKA}

Akhyar Tipan, 2015. Analisis Perlakuan Akuntansi Aset Tetap Pada Dinas Pekerjaan Umum (PU) Provinsi Sulawesi Utara. Skripsi. Jurusan Akuntansi. Fakultas Ekonomi Dan Bisnis Universitas Sam Ratulangi Manado.

Deddi, Iswahyudi, Maulidah, 2012. Akuntansi Pemerintahan. Salemba Empat. Jakarta. Diana, Anastasia dan Lilis Setiawati. 2011. Sistem Informasi Akuntansi. Andi: Yogyakarta. 
Halim Abdul \& Syam Kusufi. (2012), Halim, Abdul \& Kusufi M. Syam, 2014. Akuntansi Sektor Publik. Edisi 2. Salemba Empat, Jakarta.

Hariadi Parmono, Yanuar E. Restianto dan Icuk Rangga. Bawono. 2010. Pengelolaan Keuangan Daerah. Penerbit Salemba Empat, Jakarta.

Kolinug, Monica. 2015. Analisis Pengelolaan Aset Tetap Pada Dinas Pendapatan Pengelolaan Keuangan dan Aset Daerah Kota Tomohon. Jurnal EMBA ISSN 23031174 Vol. 3 No. 1 Maret 2015 Hal. 818-830

Mahmudi, 2011. Akuntansi Sektor Publik. Penerbit UII Press. Yogyakarta.

Mardiasmo, 2009. Akuntansi Sektor Publik. Penerbit Andi Edisi 2. Yogyakarta.

Mir Monir and Sutiyono Wahyu, 2013. Public Sector Financial Management Reform:

A Case Study Of Local Government Agencies in Indonesia, Australasian Accounting, Business and Finance Journal, 7 (4), 97-117

Odianonsen F. Iyoha, Stephen Ojeka and Ajay. 2014. Impact Of State Institution On The Quality Off Accounting Practice Innigerian. Journal Of South African. Penelitian Bisnis. Vol. 2014, ID Artikel 782.177, 37 minipages. DOI: 10,5171/2.014,782177.

Republik Indonesia, Peraturan Menteri Dalam Negeri Nomor 17 tahun 2007 tentang Pedoman Teknis Pengelolaan Barang Milik Daerah, Jakarta.

Republik Indonesia, Peraturan Menteri Dalam Negeri Nomor 13 Tahun 2006 tentang Pedoman Pengelolaan Keuangan Daerah, Jakarta.

Weygandt, J.J., Kimmel, P. D., \& Kieso, D. E. 2011. Financial Accounting. (IFRS edition). The United State of America: John Wiley and Sons, Inc. 